\title{
Impact assessment of intra seasonal temperature variations on wheat yield using CERES Wheat model
}

\author{
PRAGYAN KUMARI and A.WADOOD \\ Department of Agricultural Physics and Meteorology, BAU, Ranchi-834006 \\ Email-pragyanbau@yahoo.com
}

\begin{abstract}
A field experiment was conducted at Ranchi (Jharkhand) during rabi season of 2009-10 to 201112 with wheat cultivar K 9107 sown on three dates (Nov 20,Dec 5 and Dec 20) to calibrate and validate the CERES-wheat model. There was a good agreement between simulated and observed wheat yields, days to anthesis and days to maturity. The validated model was used to study the impact of intra seasonal temperature variation on wheat. The sensitivity analysis of CERES wheat model, with respect to temperature variations and wheat yield, revealed that increase in temperature above the normal values to $3{ }^{\circ} \mathrm{C}$, showed considerable yield reduction (12- 17 per cent) under different sowing dates. Similarly, with decrease in seasonal temperature up to $3^{\circ} \mathrm{C}$, the yield enhancement by $12-16$ per cent was observed. Sensitivity of CERES wheat model to incremental units of intra seasonal temperature showed a gradual decrease in yield as well as days to maturity under varied sowing dates. Increase in temperature $\left(3{ }^{\circ} \mathrm{C}\right.$ from normal) during $2^{\text {nd }}$ fortnight of January (16-31 $\left.1^{\text {st }}\right)$ was observed to be the most detrimental for wheat crop with respect to its yield for timely sowing date $\left(20^{\text {th }} \mathrm{Nov}\right)$ whereas it would be maximum during $2^{\text {nd }}$ fortnight of February $\left(15-28^{\text {th }}\right)$ for moderately normal sown $\left(5^{\text {th }}\right.$ Nov) and late sown crops $\left(20^{\text {th }}\right.$ Dec $)$.
\end{abstract}

Key words: CERES - Wheat, DSSAT, simulation, temperature, intra seasonal

Climate variability and its impact on agriculture production is an important issue and need proper assessment, which can be easily evaluated by crop model. There is need to quantify the growth and yield of important crops and also identify suitable adaptation measures to sustain agricultural productivity under expected large range of climatic variations. The assessment of climate change impacts on human societies and the implementation of response strategies should be underpinned by detailed scientific understanding of the magnitude and rate of climate change impacts on agriculture. Such impacts have recently been analyzed using process-based crop models to predict crop yields under both current and future climate conditions (Bindi et al. 1996, Wolf et al. 1996, Conde et al. 1997). Crop growth models have considerable potential in exploration of crop management and policy decisions for implementations and adapting to current and future climate change (Boote et al., 1996, Tsuji et al., 1998).

Wheat cultivation in Jharkhand has gained popularity in recent years and area under this crop is gradually expanding with the adoption of rainwater harvesting and reuses technique for assured irrigation. K 9107 is a promising variety of Jharkhand region by its high yielding ability with bold grains. Sudden rise in temperature during second fortnight of February has been frequently reported for the region and found that wheat crop sown on arround $20^{\text {th }}$ Nov. with an average seasonal air temperature of $17.5^{\circ} \mathrm{C}$ produced highest grain yield where as with every fortnightly delay in sowings an increase in average seasonal air temperature (18 to $20^{\circ} \mathrm{C}$ ) caused reduction in yield by 16 to 22 percent (Kumari et al 2009). Simulations of wheat yields using CERES-wheat model indicate that within season temperature deviations from normal play a prominent role in determining the final yield of normal sown wheat crop (Prabhjyot-Kaur and Hundal 2007). Wheat is sensitive to high temperature (during early and late stages of crop) but magnitude of damage depends on the variations of ambient temperature,stage of development and varieties (Asseng et al. 2011; Modarresi et al. 2010).

Climate change is a reality and we will have to develop strategies to adapt to these changes. Hence, an assessment of the possible net impact of climate change can help in formulating new strategies to mitigate negative impacts while sustaining positive impacts of climate change on crop production through proper adaptation methodologies. Keeping the above in view, an attempt was made to assess the impact of inter and intra seasonal temperature change on the productivity of wheat in 
Table 1: Observed and simulated grain yield $\left(\mathrm{kg} \mathrm{ha}^{-1}\right)$ of wheat under different sowing dates.

\begin{tabular}{|c|c|c|c|c|c|c|c|c|}
\hline \multirow[t]{2}{*}{ Sowing / Year } & \multicolumn{2}{|c|}{ 2009-10 } & \multicolumn{2}{|c|}{ 2010-11 } & \multicolumn{2}{|c|}{ 2011-12 } & \multirow[t]{2}{*}{$\mathrm{CV} \%$} & \multirow{2}{*}{$\begin{array}{r}\text { Avg } \\
\operatorname{Dev}(\%)\end{array}$} \\
\hline & Simulated & Observed & Simulated & Observed & Simulated & Observed & & \\
\hline Normal & $3900(-14.3)$ & 4550 & $4692(-3.9)$ & 4884 & $4609(2.8)$ & 4485 & 7.4 & -5.1 \\
\hline Moderately normal & $3835(2.3)$ & 3750 & $4649(10)$ & 4386 & $4553(7.3)$ & 4242 & 8.8 & 6.5 \\
\hline Late & $3212(2.2)$ & 3142 & 3921(12.1) & 3497 & $4389(22.3)$ & 3588 & 12.9 & 12.2 \\
\hline
\end{tabular}

Figures in parenthesis are deviation $\%$ for observed

Table 2: Statistical estimates for the comparison of observed and simulated number of days required to anthesis \& maturity stages of wheat (K 9107).

\begin{tabular}{|c|c|c|c|c|c|c|c|c|c|c|}
\hline \multirow[t]{2}{*}{ Variable Name } & \multicolumn{2}{|c|}{ Mean } & \multicolumn{2}{|c|}{ Std.Dev. } & \multirow[t]{2}{*}{$\mathrm{R}^{2}$} & \multirow{2}{*}{$\begin{array}{r}\text { Mean } \\
\text { Diff. }\end{array}$} & \multirow{2}{*}{$\begin{array}{r}\text { Mean } \\
\text { Abs.Diff. }\end{array}$} & \multirow[t]{2}{*}{ RMSE } & \multirow[t]{2}{*}{ D-Stat. } & \multirow{2}{*}{$\begin{array}{r}\text { Total } \\
\text { number obs }\end{array}$} \\
\hline & Obs & Sim & Obs & $\overline{\mathrm{Sim}}$ & & & & & & \\
\hline Anthesis (DAS) & 85 & 88 & 4.802 & 3.542 & 0.61 & 3 & 4 & 4.1 & 0.783 & 9 \\
\hline Yield kg ha ${ }^{-1}$ & 4058 & 4196 & 549.5 & 477.0 & 0.53 & 137 & 324 & 404.7 & 0.842 & 9 \\
\hline Maturity(DAS) & 122 & 117 & 6.2 & 5.3 & 0.74 & -5 & 5 & 5.8 & 0.799 & 9 \\
\hline
\end{tabular}

Table 3: Impact of change in temperature on days to maturity and yield of wheat under three dates of sowing (model simulated)

\begin{tabular}{|c|c|c|c|c|c|c|}
\hline \multirow{2}{*}{$\begin{array}{l}\text { Change in } \\
\text { temperature }\left({ }^{0} \mathrm{C}\right)\end{array}$} & \multicolumn{3}{|c|}{ Days to maturity } & \multicolumn{3}{|c|}{ Yield $\left(\mathrm{kg} \mathrm{ha}^{-1}\right)$} \\
\hline & $\overline{\text { Normal }}$ & $\begin{array}{l}\text { Moderately } \\
\text { normal }\end{array}$ & Late & Normal & $\begin{array}{l}\text { Moderately } \\
\text { normal }\end{array}$ & $\overline{\text { Late }}$ \\
\hline$-3^{\circ} \mathrm{C}$ & 135 & 129 & 121 & 4074 & 3914 & 3391 \\
\hline Normal & 119 & 115 & 108 & 3510 & 3470 & 3038 \\
\hline $3^{0} \mathrm{C}$ & 105 & 102 & 97 & 3095 & 2880 & 2665 \\
\hline
\end{tabular}

Jharkhand by using CERES -Wheat model to simulate the temperature variation.

\section{MATERIALS AND METHODS}

The study was conducted at Birsa Agricultural University Researchfield, located at latitude of $23^{\circ} 17^{\prime} \mathrm{N}$ and longitude of $85^{\circ} 19^{\prime} \mathrm{E}$. The soil of study site was sandy clay loam in texture. Three different planting windows were used to provide variable climatic conditions by growing wheat crop in three consecutive years 2009-10 to 2011-12. The planting times were 20 November (Normal), 5 December (moderately normal) and 20 December (Late) during three years. The experiments were laid out under Factorial Randomized Block Design, replicated three times in $3.5 \times 8$ $\mathrm{m}$ plot with row spacing of $20 \mathrm{~cm}$. Recommended doses of fertilizer and package and practices were followed for the experiment.

Climatic data regarding maximum, minimum temperature, rainfall and solar radia-tion during the study period was collected from the meteorological observatory located at $300 \mathrm{mt}$ away from the research field. To simulate a wheat variety, the model requires a set of genetic coefficients pertaining to phenology and growth. The genetic coefficient required in CERES wheat model for K9107 variety was estimated by repeated iterations in the model calculations until a close match between simulated and observed phenology and yield was obtained.CERESWheat model (DSSAT v 4.5) was run with the two year's experimental data for calibration of the model while the subsequent one year's data were used for validation of the model.Normal climatic data were used to simulate the wheat yield and derived the effect of the incremental increase and decrease in temperature on wheat yield and days to maturity. Model also simulated the effect of variations in intra season temperature by increasing the temperature by $3 \operatorname{degC}$ on wheat sown under normal, moderately normal and late conditions.

\section{RESULTS AND DISCUSSION}

Performance of wheat cultivar (K9107) simulated using CERES-wheat model was compared with three years experimental data (Rabi 2009-10 to 2011-12) sown under three dates of sowing observed grain yield data from the three years of experimentation sown under 3 dates were compared with the corresponding simulated grain yield data (Table 1). Simulated data were found to be very close 

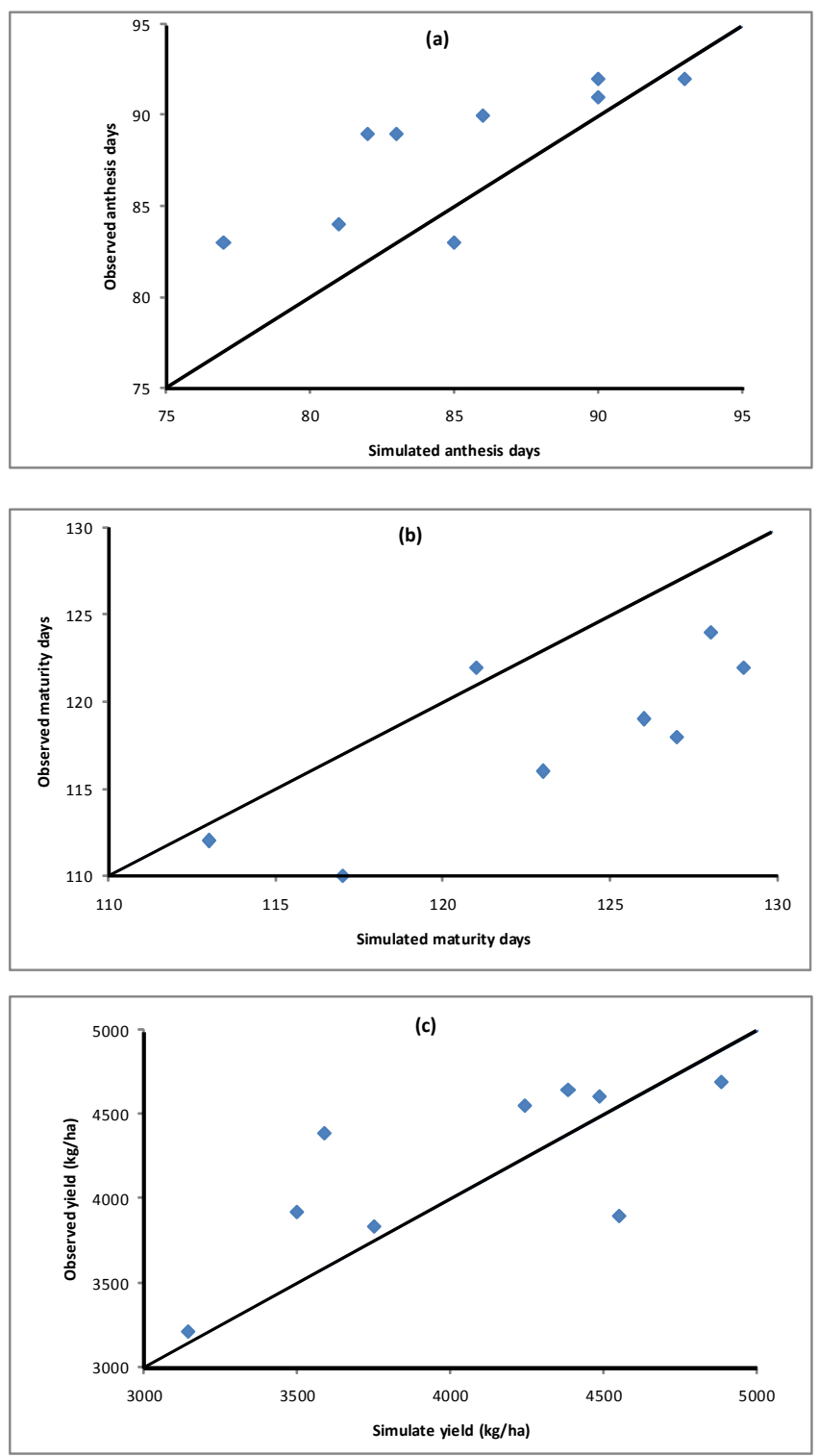

Fig 1: Observed and simulated (a) days to anthesis, (b) days to maturity and (c) grain yield $\left(\mathrm{kg} \mathrm{ha}^{-1}\right)$

to the observed ones. Thereby suggesting that the wheat yield simulation through the modified and validated crop model (CERES wheat) in reliable enough to be trusted upon for wheat yield prediction. A perusal of the data (Table 1 ) revealed that the highest match between simulated and observed ones is obtained in case of normal sowing of wheat crop, around $20^{\text {th }}$ November. However, under normal sowing condition too, a high deviation (under estimation) of -14.3 per cent was recorded in $2009-10$ where as in the subsequent years $(2010-11 \& 2011-12)$ the deviations were only $-3.9 \%$ (under estimation) and 2.8 per cent (under estimation), respectively. The average deviation, under normal sown condition, is only an under estimation of $5.1 \%$. Which is the least among the average deviation

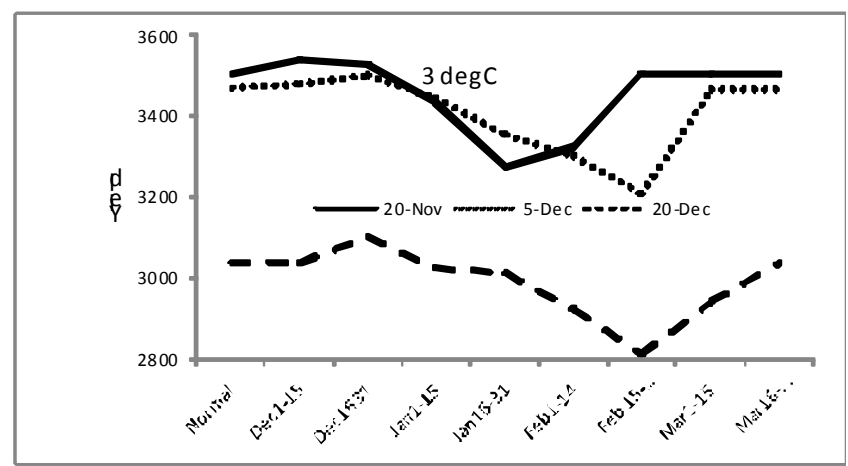

Fig.2: Effect of intra seasonal increase in temperature (3 $\operatorname{deg} \mathrm{C})$ on wheat yield $(\mathrm{kg} / \mathrm{ha})$ under different sowing dates.

obtained in case of moderately normal $(6.5 \%)$ and late (12.2\%) sown conditions. The co-efficient of variance (CV\%) too, is least in case of normal sowing $(7.4 \%)$ compared to the $\mathrm{CV}$ values of moderately normal (8.8\%) and late (12.9\%) conditions. The agreement between observed and simulated grain yield under moderately normal and late sown conditions too, is good enough. There were good agreement also between in model output and observed of number of days required to attain anthesis and maturity stages of wheat (Table 2).The simulated values for days taken to anthesis deviated from observed by 3 days with $\mathrm{D}$-index value of 0.78 . Days to maturity was under estimated by model with -4 per cent errors and D-index value of 0.79 . The model simulated the grain yields was 3.4 per cent for K-9107 which was within the range of observed value. The $\mathrm{D}$-index value for grain yield was 0.84 . This suggests that the model can be used for predicting phenology as well as grain yield of wheat (K9107).CERES wheat model was validated for days to anthesis, days to physiological maturity and grain yield (Fig 1) for all the sowing dates and the association between simulated and observed grain yield was presented.This shows that model was validated with fairly a high degree of accuracy under the given set of agronomic management, weather conditions and this can be used to plan and to workout management practices for yield maximization of wheat crop in this region.

\section{Effect of temperature variations during crop period}

Simulated yield showed that the wheat crop is sensitive to temperature. Increase in temperature by $3 \mathrm{deg}$ $\mathrm{C}$ from normal value (Table 3 ) showed that yield is likely to reduce with temperature rise under all the sowing dates. As temperature increased to $3 \mathrm{deg} C$, reduction of yield would occur by 12, 17 and 12 per cent under sowing dates. The decrease in seasonal temperature were increases the yield 
under all the sowing range

Yield reduction of wheat with rise in temperature was primarily attributed to shrinkage in crop growth period. As simulated the values of days taken to maturity would be reduced by 14,13 and 11 days with $3 \mathrm{deg} C$ rise in temperature whereas with decrease in temperature would increase the crop duration.

\section{Intra seasonal increase in temperature}

Sensitivity of CERES wheat model to incremental units of intra seasonal temperature (Fig 2) showed a gradual decrease in yield under varied sowing dates.Increase in temperature ( $3 \mathrm{deg} \mathrm{C}$ from normal) during $2^{\text {nd }}$ fortnight of January (16-31 $\left.1^{\text {st }}\right)$ is observed to be the most detrimental to wheat crop in terms of yield for normal sowing date (20 Nov) whereas it would be maximum during $2^{\text {nd }}$ fortnight of February $\left(15-28^{\text {th }}\right)$ for moderately normal $\left(5^{\text {th }}\right.$ Nov) and late $(20 \mathrm{Dec})$ sown crops. This period is coincided with the anthesis period of wheat which is most sensitive stage to thermal variation. Increase in temperature during $2^{\text {nd }}$ fortnight of December would increase the wheat yield under late sown condition. It is advisable to the farmers of Jharkhand that an additional irrigation is essentially required during $2^{\text {nd }}$ fortnight of Januaryand $2^{\text {nd }}$ fortnight of February in case of normal sowing and moderately normal to late sowing conditions, respectively for the wheat crop. This type of planning will reduce the negative impact of intra seasonal temperature rise on wheat yield.

\section{REFERENCES}

Anwar, M.R., O’Leary, G., McNeil, D., Hossain, H., Nelson, R., (2007). Climate changeimpact on rainfed wheat in southeastern Australia. Field Crops Res. 104(1-3),139-147.

Asseng,S.,Foster,I.and Turner, N.C.(2011).the impact of temperature variability on wheat yields. Global Change Biol.,17:997-1012.

Bindi, M., Fibbi, L., Gozzini, B., Orlandini, S., Miglietta, F.,( 1996). Modeling the impact of future climate scenarios on yield and yield variability of grapevine. Clim. Res., 7, 213-224.

Boote,K.J.,Jones,J.W. and Pickering,N.B.(1996). Potential uses and limitations of crop models. Agron J., 88:704-716

Chauhan, H., Khurana, N., Tyagi, A., Khurana, J., Khurana, P., (2011). Identificationand characterization of high temperature stress responsive genes in breadwheat (Triticum aestivum) and their regulation at various stages ofdevelopment. Plant Mol. Biol., 75 (1), 35-51.

Conde, C., D. Liverman, M. Flores, R. Ferrer, R. Araujo, E. Betancourt, G. Villareal, andC. Gay.(1997). "Vulnerability ofRainfed Maize Crops in Mexico to Climate Change", Climate Res.,9:1-23.

Kumari, Pragyan; Wadood,A. Singh, R.S. and Kumar, R.(2009) .Response of wheat crop to different thermal regimes under the agroclimatic conditions of Jharkhand. $J$. Agromet., 11 (1)pp 85-88.

Modarresi, M; Mohammadi,V;Zali,A. And Mardi,M.(2010).Response of wheat yield and yield related traits to high temperature. Cereal Res. Commun., 38(1): 23 -31

Prabhjyot-Kaur, and Hundal,S.S.(2007).Effect of temperature rise on growth and yield of wheat.A simulation study. J.Res.(PAU), 44 (1):6-8.

Reynolds, M.P., Nagarajan, S., Razzaque, M.A.,Ageeb, O.A.A., (2001). Heat tolerance.In: Reynolds, M.P., OrtizMonasterio, J.I., McNab, A. (Eds.), Application ofPhysiology in Wheat Breeding. CIMMYT, Mexico, pp. 124-135.

Sharma, R.C., Tiwary, A.K., Ortiz-Ferrara, G., (2008). Reduction in kernel weight as apotential indirect selection criterion for wheat grain yield under terminal heatstress. Plant Breed., 127(3), 241-248.

Tsuji,G.Y., Hoogrnboom,G. And Thornton, P.K. (1998). Understanding options for agricultural development.Kluwer Academic Publ, Dordrecht, the Netherlands.

Wolf J,Evans L.G, Semenov M.A,Eckersten H, Iglesias A( 1996).Comparison of wheat simulation models under climate change. 1. Model calibration and sensitivity analyses. Clim. Res., 7, 253-270. 